\title{
A GALIZA APÓS FRAGA
}

As eleições celebradas na Galiza em 19 de Junho de 2005 supõem um giro qualitativo no sistema político galego, trás dezasseis anos de governo ininterrupto dos conservadores do Partido Popular (PP), liderados por Manuel Fraga Iribarne. Por primeira vez na curta história da democracia galega, a soma dos votos dos partidos de esquerda supera os da direita, que deverá enfrentar o debate para a sucessão do seu líder carismático. Por outro lado, a estreita margem dos novos sócios de governo, como também as diferentes sensibilidades e projectos dos dois partidos, PSdG-PSOE (Partido dos Socialistas de Galicia-Partido Socialista Obrero Español) e BNG (Bloco Nacionalista Galego), colocam dúvidas sobre o futuro do seu pacto, ainda mais se levarmos em conta o contexto político espanhol actual, com debates abertos sobre as reformas substanciais dos Estatutos de autonomia das outras duas «nacionalidades históricas ", País Basco e Catalunha. Pode sugerir-se, enfim, que as mudanças políticas acontecidas na Galiza supõem uma perda da autonomia do sistema político galego, cada vez mais influído pela política e a dinâmica partidária espanhola.

\section{Galicia after Fraga}

The regional elections held in Galicia on the $19^{\text {th }}$ of June 2005 meant a crucial transformation of the Galician political system after sixteen years of conservative government by the Partido Popular (PP), led by Manuel Fraga Iribarne. For the first time in the short history of Galician democracy, the sum of votes of leftwing parties was greater than that of the PP. This party must also face a debate about the succession of its charismatic leader. The small advantage of the new partners to the government, as well as the diverse points of view and political projects of these parties, the PSdG-PSOE (Partido dos Socialistas de GaliciaPartido Socialista Obrero Español) and the BNG (Bloco Nacionalista Galego), have brought about hesitations about the future of their alliance. Moreover, it is important to take into account the current Spanish political context with an open controversy about substantial changes in the "Estatutos" of autonomy in the other "Historic Nationalities" of Spain: the Basque Country and Catalonia. It is possible to suggest that the political changes occurring in Galicia constitute a relative loss of autonomy of the Galician Political System, since this is influenced by the Spanish political models and party struggles.

\section{La Galice après Fraga}

Les élections qui ont eu lieu en Galice le 19 juin 2005 ont signifié une importante transformation qualitative du système politique galicien après seize ans de gouvernement ininterrompu des conservateurs du Partido Popular (PP) sous la direction de Manuel Fraga Iribarne. Pour la première fois dans la courte histoire démocratique galicienne, la somme des voix des partis de gauche a dépassé celle du PP. Ce parti devra, en plus, faire face à un débat interne sur la succession de son leader charismatique. Par ailleurs, l'étroite marge de voix des nouveaux partenaires au gouvernement, PSdG-PSOE (Partido dos Socialistas de 
Galicia-Partido Socialista Obrero Español) et BNG (Bloco Nacionalista Galego), et leurs points de vue et projets politiques différents ont provoqué des interrogations sur la viabilité de leur alliance. En outre, il faut tenir compte du contexte politique général de l'État espagnol, avec des débats ouverts sur les importantes réformes proposées pour les «Estatutos » d'autonomie dans les deux autres «Nationalités historiques» d'Espagne, le Pays Basque et la Catalogne. Enfin, les mutations politiques actuelles en Galice pourraient être la manifestation d'une relative perte d'autonomie du système politique galicien, chaque fois plus intégré à la politique et à la dynamique des partis espagnols.

$\mathrm{E}$ m 1980 a Galiza via aprovado o seu Estatuto de Autonomia. Um ano depois celebrava as primeiras eleições autonômicas. Naquela altura, o sistema político galego emergente gozava já dum certo grau de independência a respeito do sistema político espanhol, em base à sua condição de "nacionalidade histórica ». O alto nível de abstenção eleitoral ou a fragmentação política eram as suas características básicas, as quais haviam de variar até chegarmos ao momento de transição actual. Assim, se nas primeiras eleições eram seis os partidos com representação parlamentar, hoje são apenas três e a abstenção está nos níveis habituais nas democracias ocidentais. Outra mudança chave no sistema político galego é o próprio governo de esquerdas, já que o País esteve sempre governado pela direita mais tradicional.

O primeiro governo da autonomia, formado pela UCD (União do Centro Democrático), não teve maioria absoluta. Sendo uma confederação de partidos de Direita, não sobreviverá às tensões internas, fracturando-se pouco depois das eleições estatais de 82, quando o PSOE obteve a sua primeira maioria absoluta em Espanha. A sua oposição ao chamado "Estado das autonomias », entre outros factores, propiciou a chegada ao poder de outro partido de direitas, Alianza Popular (AP), de que era presidente e fundador Manuel Fraga Iribarne. No entanto, o seguinte presidente galego não havia ser ele, mas Fernández Albor, que necessitou o apoio da Coligação Galega (CG), um partido charneira, com uma orientação mais liberal e galeguista. Seria este partido o que constituiria, junto com o PSOE e PNG-PG (Partido Nacionalista de Galicia-Partido Galeguista) a efémera experiência do governo tripartidário (1987-1989), após a retirada da confiança de CG ao governo da Direita.

Assim, até a chegada de Fraga Iribarne, a Direita na Galiza estava fraccionada em vários partidos. Porém, quando em 1989 Fraga Iribarne obteve a primeira maioria absoluta para AP, deixa de precisar o apoio de CG, que se descompõe rapidamente. Daí para a frente, já com Fraga na Presidência, Galiza será a excepção à década de domínio socialista em todo o Estado, constituindo uma espécie de bastião da Direita, para além duma «nacionalidade histórica » não nacionalista, oposta a País Basco e Catalunha. Portanto, trás a desaparição de CG, o sistema político galego vai caminhando para um sistema de três partidos : depois de $\mathrm{CG}$ chega também o declínio do outro sócio do governo tripartidário, PNG-PG, integrado na estrutura do BNG (Bloque Nacionalista Galego), que em 1993 se converte na segunda força política galega, superando aos socialistas. Em 2001, o nacionalismo parece ter a oportunidade de vencer o fraguismo, mas apesar de que o PP perde votos, a abstenção cresce, o qual prejudica à oposição. 
Assim, o falhanço dos nacionalistas na sua tentativa de se constituírem em alternativa de governo a Fraga Iribarne foi a causa do seu declínio e o começo da ascensão do PSOE que, já da mão de Emilio P. Touriño (que assume a direcção do partido em 1998), vai lutar nos anos seguintes por recuperar o terreno perdido perante o nacionalismo. Os resultados eleitorais de 2005, portanto, são a consequência não só do "efeito Zapatero », como explicaremos, mas também do sucesso de Touriño na sua pacificação interna do PSOE na Galiza.

\section{9-2005 : a etapa Fraga}

O primeiro facto a considerarmos na análise da Galiza pós-fraguista é a sua falta de dinamismo demográfico. Assim, se em 1991 a Galiza tinha 2731669 habitantes, em 2001 a cifra baixava até os 2695880 habitantes ${ }^{1}$. Mesmo assim, apesar de que o rápido envelhecimento da população e a perda de habitantes da Galiza eram fenómenos já detectáveis na década de 80', eles não foram solucionados entre os anos 1989 e 2005 e a Galiza chegou a uma situação que poderíamos denominar de «estagnação demográfica ». Para demonstrar isto, achegamos uma tabela e mais uma pirâmide de idades (vide infra). Em todo o caso, pensamos que pode ser um dado muito esclarecedor a idade média na Galiza, que se sitúa hoje em 43,9; se a isto, sumamos um índice de envelhecimento do 130,7 - sempre segundo dados do IGE (Instituto Galego de Estatística) - temos decerto uma boa medida dessa «estagnação demográfica » em que vive a Galiza.

Quadro I. - INDiGAdoRES DE POPULAÇÃo I99I-2005

\begin{tabular}{lccc}
\hline$\%$ de população... & menor de 20 anos & entre 20 e 64 anos & de 65 e mais anos \\
\hline \multicolumn{3}{c}{ A Corunha } \\
\hline 1991 & 26,5 & 58,5 & 15,0 \\
1996 & 22,2 & 60,8 & 16,9 \\
2000 & 18,6 & 62,4 & 19,0 \\
2004 & 16,4 & 63,4 & 20,2 \\
$2005^{*}$ & 16,1 & 63,8 & 20,1 \\
\hline & & & \\
\hline 1991 & 21,7 & 56,3 & 21,9 \\
1996 & 19,0 & 56,4 & 24,6 \\
2000 & 16,4 & 56,9 & 26,7 \\
2004 & 14,5 & 57,5 & 28,1 \\
$2005^{*}$ & 14,1 & 58,2 & 27,7
\end{tabular}

\footnotetext{
${ }^{1}$ São dados oficiais fornecidos pelo Instituto Nacional de Estatística espanhol (INE).
} 
Quadro I (cont.)

\begin{tabular}{lccc}
\hline$\%$ de população... & menor de 20 anos & entre 20 e 64 anos & de 65 e mais anos \\
\hline \multicolumn{4}{c}{ Ourense } \\
\hline 1991 & 21,9 & 56,0 & 22,0 \\
1996 & 18,9 & 56,3 & 24,6 \\
2000 & 16,3 & 56,8 & 26,9 \\
2004 & 14,5 & 57,5 & 28,1 \\
$2005^{*}$ & 14,1 & 57,8 & 28,1 \\
\hline \multicolumn{5}{c}{ Pontevedra } \\
\hline 1991 & 29,4 & 57,3 & 13,3 \\
1996 & 24,7 & 60,3 & 15,0 \\
2000 & 20,6 & 62,5 & 16,9 \\
2004 & 18,4 & 63,8 & 17,8 \\
$2005^{*}$ & 18,1 & 64,1 & 17,7 \\
\hline
\end{tabular}

C (A Corunha), L (Lugo), Ou (Ourense), Po (Pontevedra).

*Ano 2005: dados provisórios.

Fonte: Elaboração própria a partir dos dados do Instituto Galego de Estatística.

Evidentemente, o baixo dinamismo demográfico é um fenómeno resultado duma multiplicidade de factores e não se pode culpar apenas aos políticos. Porém, é legítimo esperar deles medidas que combatam os efeitos negativos de tal dinâmica. O escasso dinamismo demográfico manifesta-se hoje na emigração de muitos jovens, que seguem a ver-se obrigados a procurar trabalho nas partes mais desenvolvidas do Estado ou da Europa. Aliás, é preciso acrescentar que a Galiza é um território com uma das taxas de natalidade mais baixas da Europa.

Estão ainda por avaliar os efeitos da precariedade e a temporalidade dos trabalhos dos jovens na mínima disposição a terem filhos. Seja como for, para além da problemática demográfica, poderia falar-se ainda na crise dos vínculos sociais

Pirâmide idades, Galiza 2003

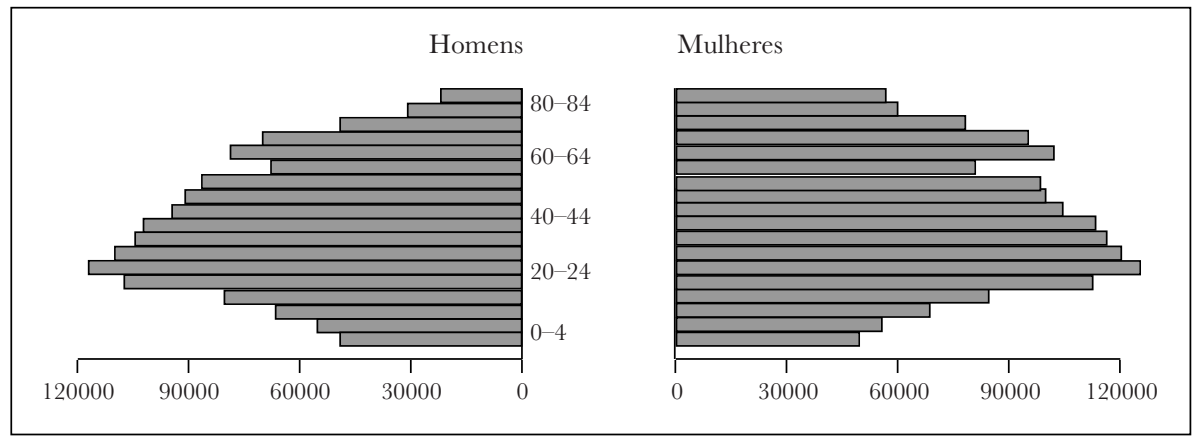

Fonte: Elaboração própria a partir dos dados do Padrón municipal de habitantes de 2003. 
tradicionais, resultado de outra crise, esta de carácter socio-territorial, em que apenas as principais cidades são capazes de resistir como centros de actividade e emprego, face a um médio rural em profunda crise económica e demográfica. A falta de vitalidade demográfica galega está, portanto, claramente associada à situação da economia e à organização do território.

No que diz respeito às infra-estruturas de vertebração territorial, são evidentes os progressos realizados durante o governo de Manuel Fraga. Assim, da Conselharia de Política Territorial foram impulsadas medidas económicas que visavam animar e modernizar as actividades produtivas, através da construção de parques empresariais e centros tecnológicos, sobretudo em áreas rurais do interior do país. Aliás, outro objectivo do governo galego foi a posta em funcionamento de novas infraestruturas de transporte rodoviário, capazes de acabar com o tradicional isolamento da Galiza, criando uma rede de conexões funcionais entre os principais nós da rede urbana galega e ibérica. Porém, há de dizer-se que muitos dos empreendimentos iniciados, realizados graças aos Fundos europeus, nem sempre foram os mais acertados, pelo menos do ponto de vista da sustentabilidade social e territorial.

Todavia, a principal objecção que se pode fazer a todos estes empreendimentos, do ponto de vista territorial, é a escassa adequação à demanda existente. Desta forma, muitos parques industriais e viais de comunicação ficaram infra-utilizados, enquanto certas áreas urbanas seguem a precisar deles (a área metropolitana de Vigo, nomeadamente). Por outra parte, o governo de Fraga Iribarne também não foi capaz de vertebrar o território, favorecendo assim de forma indirecta o desequilíbrio das duas Galizas (tão rendível ao PP em termos eleitorais), reflexo em qualquer caso da despreocupação do seu governo pelo progressivo declínio dos sectores produtivos galegos. Desde São Caetano (sede do governo autónomo) chegou a ser defendida a perda de importância da agricultura no Produto Interior Líquido galego como uma melhora per se da economia galega, apesar de não terse produzido um crescimento paralelo nos outros sectores. Não houve, enfim, uma política florestal sustentável nem ajudas para fazer viáveis as explorações ganadeiras. Assim mesmo, também não houve uma política industrial e a maior preocupação a respeito do rural foi a construção de estradas que unem aldeias esmorecidas, que não vão ver a sua economia revitalizada apenas por estar unidas entre si por um fio de asfalto.

Após dezasseis anos de governo conservador, persistem também as carências no que diz respeito à inovação e o desenvolvimento, pois as políticas económicas e de formação de recursos humanos continuaram a privilegiar sectores tradicionais com escasso valor acrescentado, o que levou também à criação de «subemprego » e à falta de aproveitamento de uns recursos humanos altamente qualificados que, em muitos casos, vão procurar um futuro melhor em centros de investigação e desenvolvimento de fora da Galiza. Neste sentido, há cifras claras : o investimento em I + D + i na Galiza não passa do 0,86 \% do PIB galego (no conjunto do Estado é de 1,1\% e a média da UE, 1,9\%) e o número de investigadores é de 3 por cada 1000 pessoas, enquanto esta cifra sobe até 3,7 investigadores por mil activos no conjunto de Espanha e até 5,1 na União Europeia ${ }^{2}$. Ora, ainda que

\footnotetext{
${ }^{2}$ Ver o Diario de Pontevedra, 25 de Julho de 2005.
} 
podem reconhecer-se avanços neste campo (o investimento em I + D há dez anos representava apenas o $0,5 \%$ do PIB, o principal atranco para o desenvolvimento reside no forte papel do sector público nos investimentos realizados (mais do $61 \%$ ) face ao débil compromisso do sector privado galego com a inovação.

Talvez um dos piores aspectos do governo de Fraga Iribarne foi a escassa atenção prestada às políticas sociais e de emprego. Certamente, foi um facto positivo a criação da RISGA (Renda mínima de integração social galega), que demonstrou ser porém uma medida bem insuficiente, ao serem inexistentes as políticas específicas de atenção aos maiores e os jovens (apesar da construção constante de centros sociais ou da existência duma conselharia específica). O resultado actual é claro, pois as taxas de paro na Galiza são do $12,5 \%$, dois pontos por acima da média estatal; a isto é preciso acrescentar o fluxo de emigração produzido na última década, na altura em que o Estado espanhol passou a ser receptor líquido de emigrantes. O chamado "Plano Labora », que visava facilitar contratos dum ano aos jovens sem experiência laboral, foi uma tentativa de solução para o desemprego juvenil, mas não estava em condições de combater a instabilidade e a precariedade que caracterizam o emprego na Galiza, mas tudo o contrário. Aliás, o gasto adequado em I + D + i também não permitiu modificar a ineficiente estrutura empresarial galega. Por último, houve pouca preocupação nas políticas sociais pela igualdade real dos sexos e pela luta contra a violência doméstica, apesar da existência de uma lei relativa, carente de resto de objectivos ou políticas concretas.

No que diz respeito à saúde e ao ensino, houve com certeza uma clara melhora dos serviços desde finais de 1970, sendo um fenômeno ligado ao desenvolvimento do «Estado do Bem-estar» em Espanha. Porém, já desde finais dos anos 1980 os sistemas de saúde (não apenas o galego) mostraram-se cada vez mais deficitários e incapazes de assumir a demanda em crescimento de serviços assistenciais (especialmente gravosos na Galiza por causa do envelhecimento demográfico e à dispersão geográfica da sua população). Isto provocou a aparição de longas listas de espera para as consultas com especialistas e as intervenções cirúrgicas. No entanto, embora a generalização desta crise dos sistemas públicos de saúde possam indicar o seu carácter estrutural e a débil capacidade de reacção dum governo regional, duvida-se da oportunidade das acções tomadas pelo governo de Fraga, ao ter-se dado pulo a fundações e clínicas sanitárias privadas, financiadas em grande parte com verbas públicas, em vez de ter melhorado e administrado de forma eficiente os hospitais públicos já existentes. Relativamente ao ensino, a principal crítica à acção de governo de Fraga é a sua falta de compromisso com a modernização tecnológica de escolas e liceus, mas também com o processo de normalização lingüística do galego (variante do português falado na Galiza) e a persistência de elevados níveis de insucesso escolar, junto à existência dum sistema educativo a « duas velocidades », resultado da situação de relativo privilégio concedida às instituições de ensino privadas.

Quanto às políticas ambientais, as decisões da etapa Fraga (como as dos anteriores) podem considerar-se tímidas e pouco críveis. Assim, na Galiza convivem ainda uma sociedade ainda fortemente rural, pouco industrializada, com algumas das indústrias mais poluentes do Estado (transformados da madeira, térmica, alumínio, etc.). Além disso, o governo de Fraga Iribarne promoveu uma política de montes baseada no mantimento e protecção de grandes massas florestais para o aproveitamento silvícola. Em realidade, tal política supus imensas plantações de 
eucaliptos e pinheiros (espécies que ardem muito facilmente), as quais ocupam hoje quase a metade da superfície do território da Comunidade autónoma sendo utilizadas nas diferentes indústrias dependentes da madeira. Por outro lado, a terrível praga dos incêndios florestais está relacionada por um lado, com o abandono do médio rural e por outro, com a forte pressão urbanística, tanto sobre o monte como sobre o litoral, que é fonte de amplos benefícios especulativos, o que rende difícil o cumprimento estrito da regulamentação em vigor. É obrigado acrescentar ainda a insuficiência dos meios, tanto materiais como estratégicos, para a protecção e saneamento dos litorais, tão importantes para a economia do País. Esta insuficiência manifestou-se com crueldade na hora de enfrentar a limpeza das costas galegas trás a catástrofe provocada pelo afundamento do petroleiro « Prestige », em Novembro de 2002. Em resumo, pode dizer-se que durante o governo de Manuel Fraga Iribarne existiu sempre pouca preocupação pela proteção e posta em valor dos principais valores ecológicos e paisagísticos da Galiza.

Agora, no referente à projecção exterior da Galiza, Fraga empreendeu uma cooperação firme com o Norte de Portugal, apadrinhando uma série de estruturas permanentes com vistas à criação duma rede de interesses políticos e económicos comuns, expressados na constituição da euroregião Galiza-Norte de Portugal e que entendem a cooperação permanente no seio da «Comunidade de Trabalho Galiza-Norte de Portugal » existente já desde 1991. Tal estrutura criou-se para dar visibilidade a ambos territórios, visando a constituição dum lobby galaico-luso com uma estratégia única a nível internacional.

No momento de avaliar a própria acção de governo, o ex-presidente manifestava recentemente que durante o seu mandato, Galiza experimentou claros avanços em todos os âmbitos, progredindo na identificação majoritária e positiva dos galegos e galegas com uma comunidade culturalmente diferenciada ${ }^{3}$. No entanto, e apenas como uma prova da distância entre as palavras e os factos, podemos ter presentes os dados fornecidos pela «Mesa pela Normalização Linguística » sobre a política linguística de Fraga Iribarne. Assim, sempre segundo dados dessa organização, o galego perdeu terreno como língua inicial (do 62,4 \% ao 56,0 \%), descendendo a percentagem das famílias bilingues dos $11,4 \%$ aos 9,9 \% (de média) e aumentando o espanhol como língua inicial do 25,6 \% ao $33 \%$. Portanto, se o principal factor de identidade cultural diferenciada da Galiza é a sua língua, vemos como nos últimos quinze anos se produziu um espectacular retrocesso no número de falantes do português da Galiza. Portanto, face a essa visão ufanista de Fraga Iribarne, julgamos que o seguinte excerto do discurso de investidura do novo Presidente, Emilio P. Touriño, pode ajustar-se mais à situação real em que se encontra a Galiza após o governo de Fraga Iribarne:

«A Galiza que herdamos caracteriza-se pelos desequilíbrios. O desequilíbrio dum interior em crise, envelhecido, com uma agricultura desmantelada. $\mathrm{O}$ desequilíbrio duma costa explorada em excesso, com periferias urbanas pouco qualificadas, de urbanismo caótico. Desequilíbrios resultado duma sorte de conformismo social, dum "deixar fazer" que, desgraçadamente, contou sempre com a cumplicidade do governo da Galiza ».

${ }^{3}$ A Nosa Terra, 1 186, 27 de Julho-3 de Agosto de 2005. 


\section{Análise dos resultados eleitorais}

Até aqui foi revisto o legado político do governo de Fraga. Agora, o nosso intuito é analisar o resultado das últimas eleições, que embora possam dar pé a muitas leituras subjectivas, têm umas consequências objectivas, isto é, a perda do poder por parte da Direita e a formação dum governo de socialistas e nacionalistas. Ora bem, dito isto, pode afirmar-se que o momento histórico está cheio de incertezas, nomeadamente no relativo ao futuro do PP. Sem o líder carismático que levou o partido até a maioria absoluta, muitos vêem possível a fragmentação do partido conservador. Por outro lado, não deixa de ser certo que um governo de coligação pode ser lido em chave de instabilidade política e pode ser visto, também, como a expressão duma mudança histórica no sistema político galego, que fornece a oportunidade para o relanço da economia e a identidade diferenciada no seio do Estado espanhol. Assim, em termos de identidade política, os resultados representarão, na nossa opinião, um passo decisivo no processo de integração do sistema político galego dentro do espanhol. Assim, será difícil que o sistema político volte à situação anterior a Fraga, agora que a implantação na Galiza dos partidos estatais, PP e PSOE, é cada vez maior. Por outro lado, a opção nacionalista de esquerda, representada pelo BNG, apesar da perda de votos e de deputados, consolida e incrementa a sua presença institucional, entrando por primeira vez no governo autonômico.

Tomando, pois, em consideração os resultados das últimas eleições autonômicas (vid. quadro II infra) pode constatar-se a perda generalizada de apoios eleitorais ao PP e ao BNG e a forte ascensão do PSdeG-PSOE. É significativo que parte do PSdeG-PSOE sujeite as possibilidades de êxito do governo de coligação ao desejo de José Luis Rodríguez Zapatero de integrar o BNG no debate geral sobre as reformas territoriais, quando o PSOE, em qualquer caso, não poderia governar sem o apoio nacionalista. Seja como for, os resultados eleitorais expressam primeiramente uma vontade de mudança no eleitorado, que fazia previsível a formação dum governo de alternância ao PP, composto por duas forças que competem por um mesmo espaço eleitoral. Uma novidade decisiva foi a importante participação do presidente espanhol na campanha eleitoral galega. Com feito, ele foi o primeiro em afirmar em Madrid a fé num acordo com os nacionalistas, apresentando-se a si próprio como garante do tal pacto.

Quadro II. - Eleições autonômicas I98I-2005

\begin{tabular}{lcccccccc}
\hline & AP/PP & UGD & GG & $\begin{array}{r}\text { PSdG/ } \\
\text { PSOE }\end{array}$ & $\begin{array}{c}\text { PGG/ } \\
\text { EU }\end{array}$ & BNG & EG & Total \\
\hline 1981 & 26 & 24 & - & 16 & 1 & 3 & 1 & 71 \\
1985 & 34 & - & 11 & 22 & - & 1 & 3 & 71 \\
1989 & 38 & & 2 & 28 & - & 5 & 2 & 75 \\
1993 & 43 & & - & 19 & - & 13 & - & 75 \\
1997 & 42 & & & 13 & 2 & 18 & & 75 \\
2001 & 41 & & & 17 & - & 17 & & 75 \\
2005 & 37 & & & 25 & & 13 & & 75 \\
\hline
\end{tabular}

Fonte: Elaboração própria. 
O pacto entre socialistas e nacionalistas supõe a perda das eleições para o PP, apesar de ser ainda a primeira força política em quase todos os municípios da Galiza (cf. Mapa 1), incluídas as principais cidades. Ora bem, é preciso levar em conta que o PP cresceu em intenção de voto em apenas 22 concelhos da Galiza e que estes representam o 2,4\% da população ${ }^{4}$. Portanto, os resultados eleitorais supõem um giro à esquerda histórico, pois faz perder ao Centro-direita o que se considerava a sua hegemonia natural na Galiza. Como resume Anxo Lugilde, o retrocesso eleitoral do $\mathrm{PP}$, apesar de não ser tão forte como se esperava, significa a perda da maioria absoluta e a continuação da tendência iniciada já em 1997, de desgaste do PP nas cidades, estendendo-se nesta ocasião aos centros de menor população ${ }^{5}$. Por outras palavras, o governo liderado por Manuel Fraga Iribarne foi vítima da sua incapacidade para renovar a sua oferta política, ajustando-a às mudanças sociais e ao declínio inevitável da Galiza rural, que constitui ainda o celeiro dos votos da Direita.

Mapa 1: Partido mais votado por concelhos

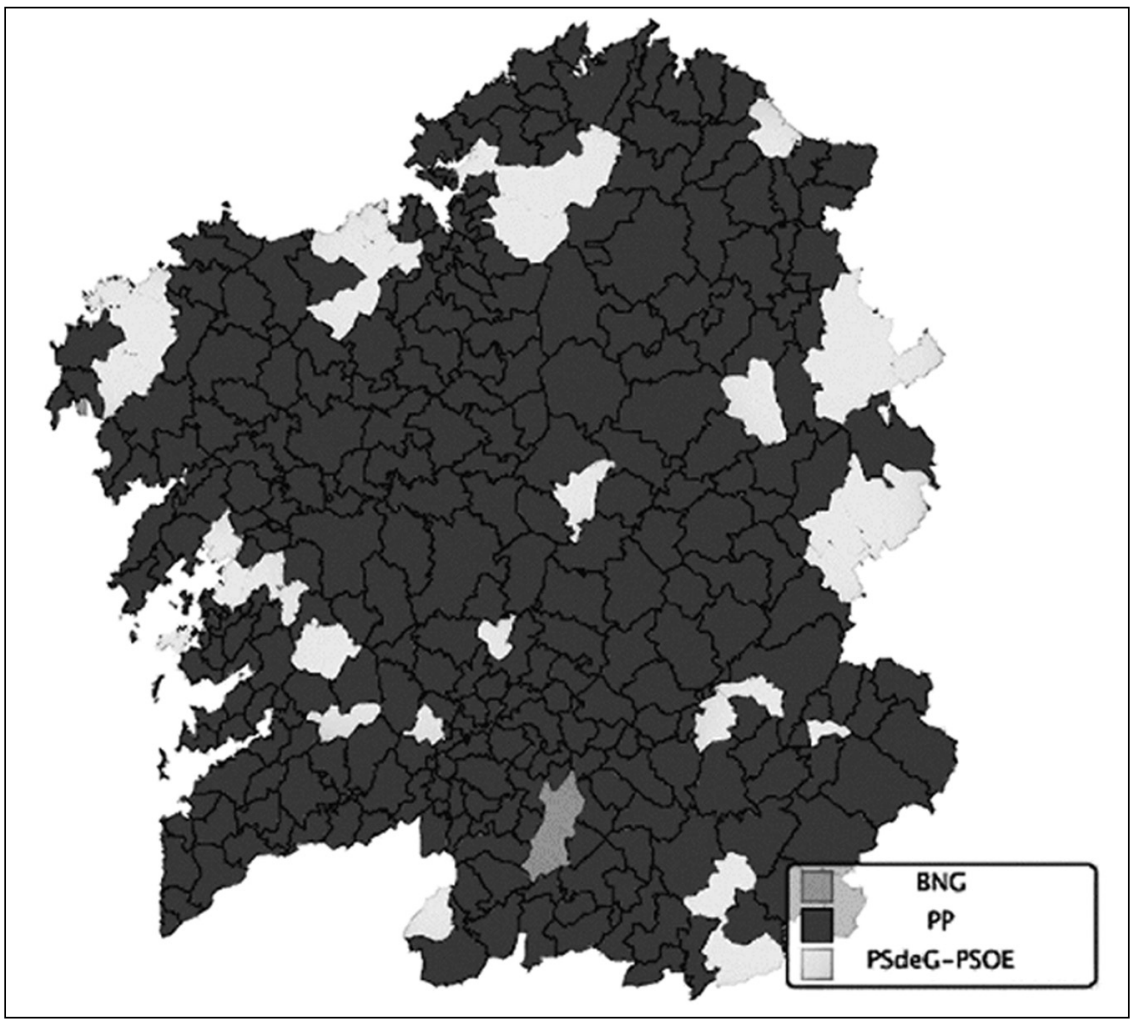

Fonte: Elaboração própria a partir de dados institucionais tirados de $<$ http:www.eleccionsgalegas2005.org/xunta.es>.

${ }^{4}$ São dados tirados do jornal La Voz de Galicia, 14 de Agosto de 2005 : 12-13.

${ }^{5}$ A. Lugilde \& X. CAarreira, El fin del fraguismo, Corunha, Biblioteca galega, 2005. 
Assim, o PP perdeu a maioria eleitoral nas comarcas costeiras e nas áreas metropolitanas de Lugo, Ourense, e Santiago e ficou perto de perdê-la também em muitas comarcas da Galiza interior. O PSdG é apenas a primeira força em votos nas comarcas da Corunha e da Fonsagrada, no extremo oriental da Galiza, enquanto o BNG emerge como segunda força em comarcas do Interior como Alhariz-Maceda, perto de Ourense, e da Galiza costeira, como o Morraço e o Barbança. Por outro lado, em quase todas as zonas onde o PP entra em crise, o PSdG aumenta os seus apoios eleitorais, em núcleos próximos aos centros urbanos de importância, figurando algumas destas áreas entre as menos envelhecidas da Galiza (vid. mapa 2, infra).

Por outro lado, é verdade que os socialistas se viram favorecidos nestas eleições não apenas pelo desejo de mudança, mas também tanto pela desconfiança e as baixas expectativas que gerava um candidato como Touriño, e também pelas sondagens eleitorais que davam por feita a perda da maioria absoluta do PP, fazendo por primeira vez acreditável a possibilidade de uma mudança no governo da Junta. O PSOE foi beneficiado ainda por um aumento da participação nas cidades e nos concelhos menores de 500 habitantes, o que supõe um fortalecimento na Galiza rural, feudo do PP. Aliás, o PSOE supera já o seu sócio de governo em toda classe de municípios, sendo a distância menor no caso das vilas.

Para entender o êxito do PSOE, é fundamental o retrocesso do PP naquele que se considerava o seu feudo, porque significa o princípio do fim, talvez, de uma forma de fazer política, a do cacique que troca votos por favores. Ora bem,

Mapa 2: Resultados por comarca

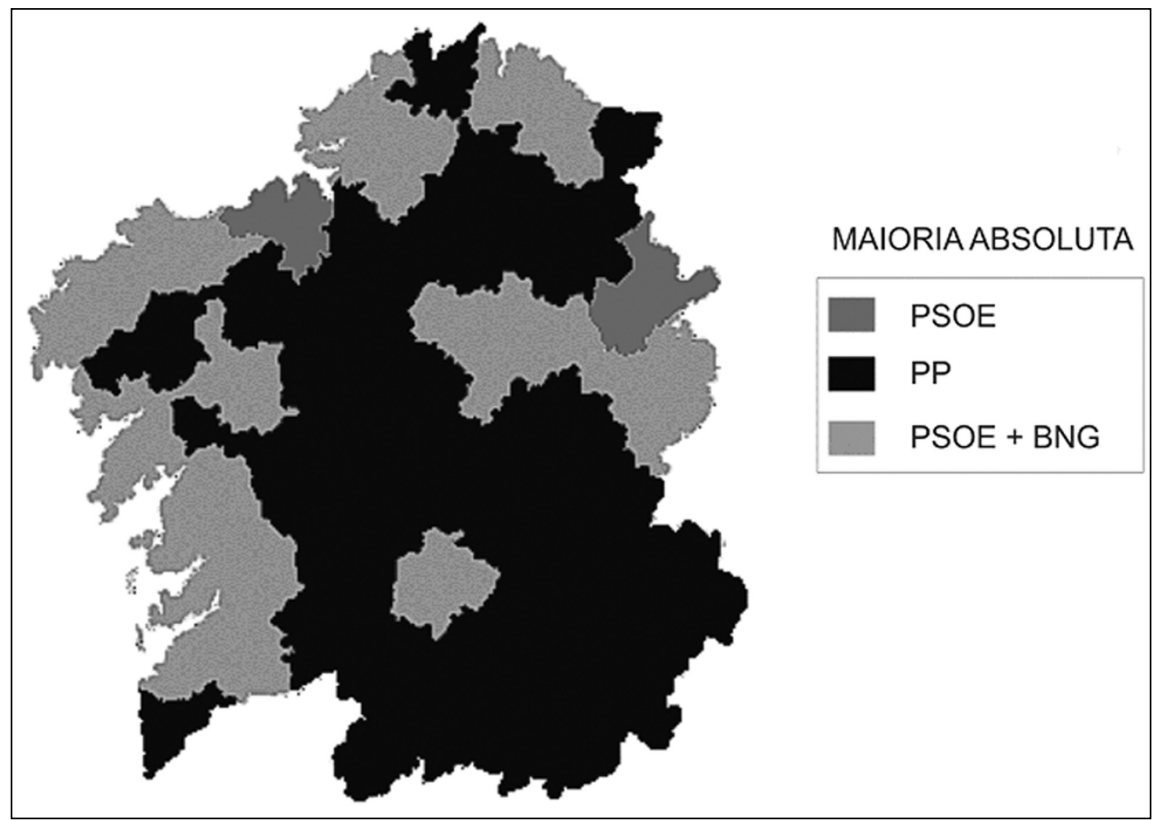

Fonte : Elaboração própria. 
Mapa 3 : Evolução do voto do PsdeG-PSOE

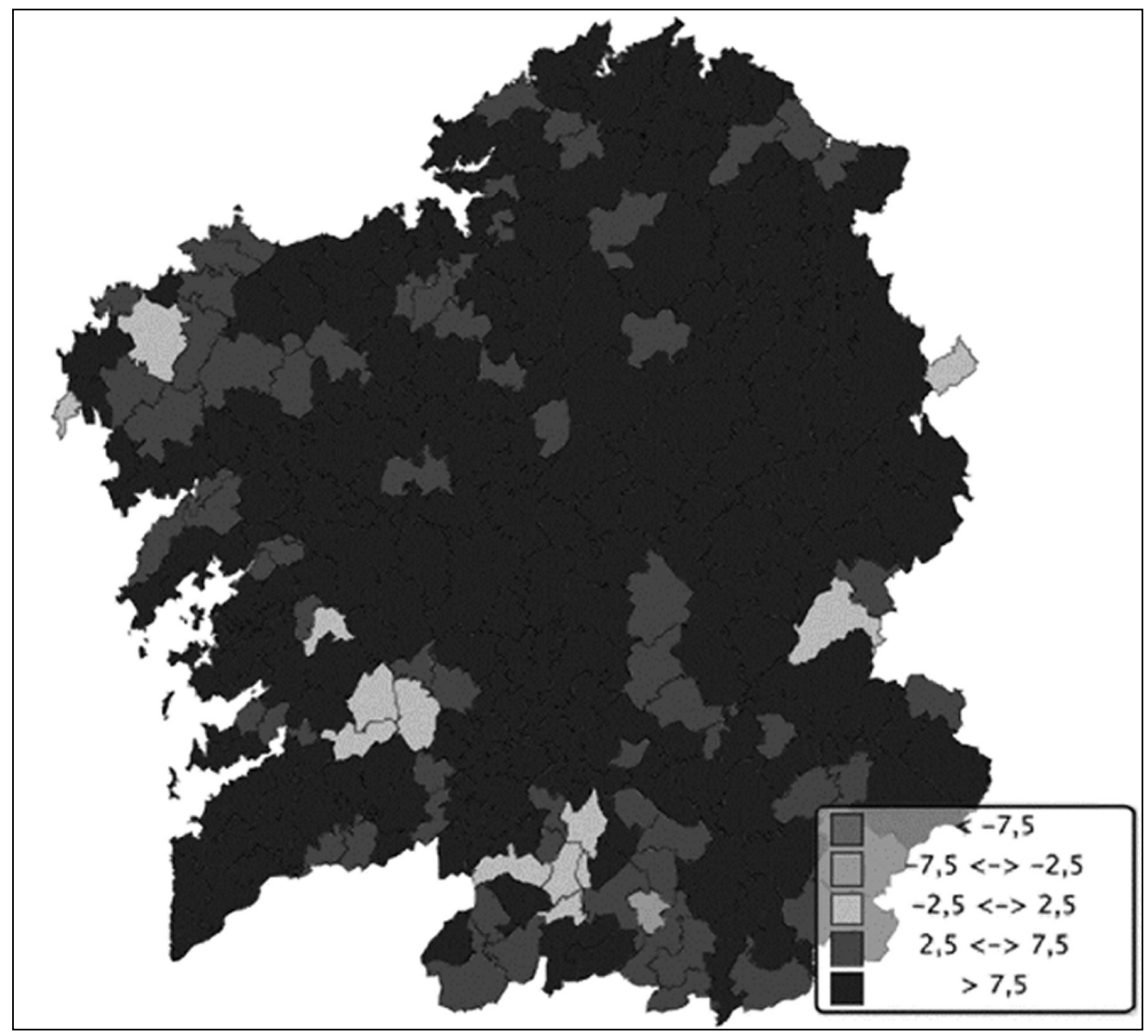

Fonte : Elaboração própria a partir de dados institucionais tirados de www.eleccionsgalegas2005.org/xunta.es.

é preciso lembrar que se o PP quedou tão só a um deputado da maioria parlamentária foi não apenas pelo forte apoio que segue recebendo no rural e na cidade, mas também como consequência do sistema proporcional e duma lei eleitoral que prima as províncias do Interior, muito mais despovoadas e envelhecidas (a reforma eleitoral foi uma das primeiras leis aprovadas pelo governo de Fraga e com certeza será uma das primeiras do novo governo). Assim, a distribuição eleitoral na Galiza tem muito mais a ver com a pirâmide populacional que com o cleavage rural/urbano ao que recorrem a maioria dos analistas. $\mathrm{O}$ voto da província de Pontevedra, decisivo no resultado final das eleições, exprime bem a mudança de tendência política, pois foi ali onde o descenso de votos do PP foi mais acusado, quer na área metropolitana de Vigo, quer na própria cidade onde se concentra um terço da população provincial. Na cidade olívica, o PP perdeu como esperava muitos votos, mas desta vez não foi capaz de compensá-los com os votos dos seus bastiões nas comarcas vizinhas do Morraço e o Deça.

O BNG afiança a sua posição nas vilas, isto é, nos centros de população entre 10000 e 50000 habitantes, que são também os sítios onde mais votos perdeu o PP. Assim, apesar da perda de quatro deputados (que representam, atenção, apenas 


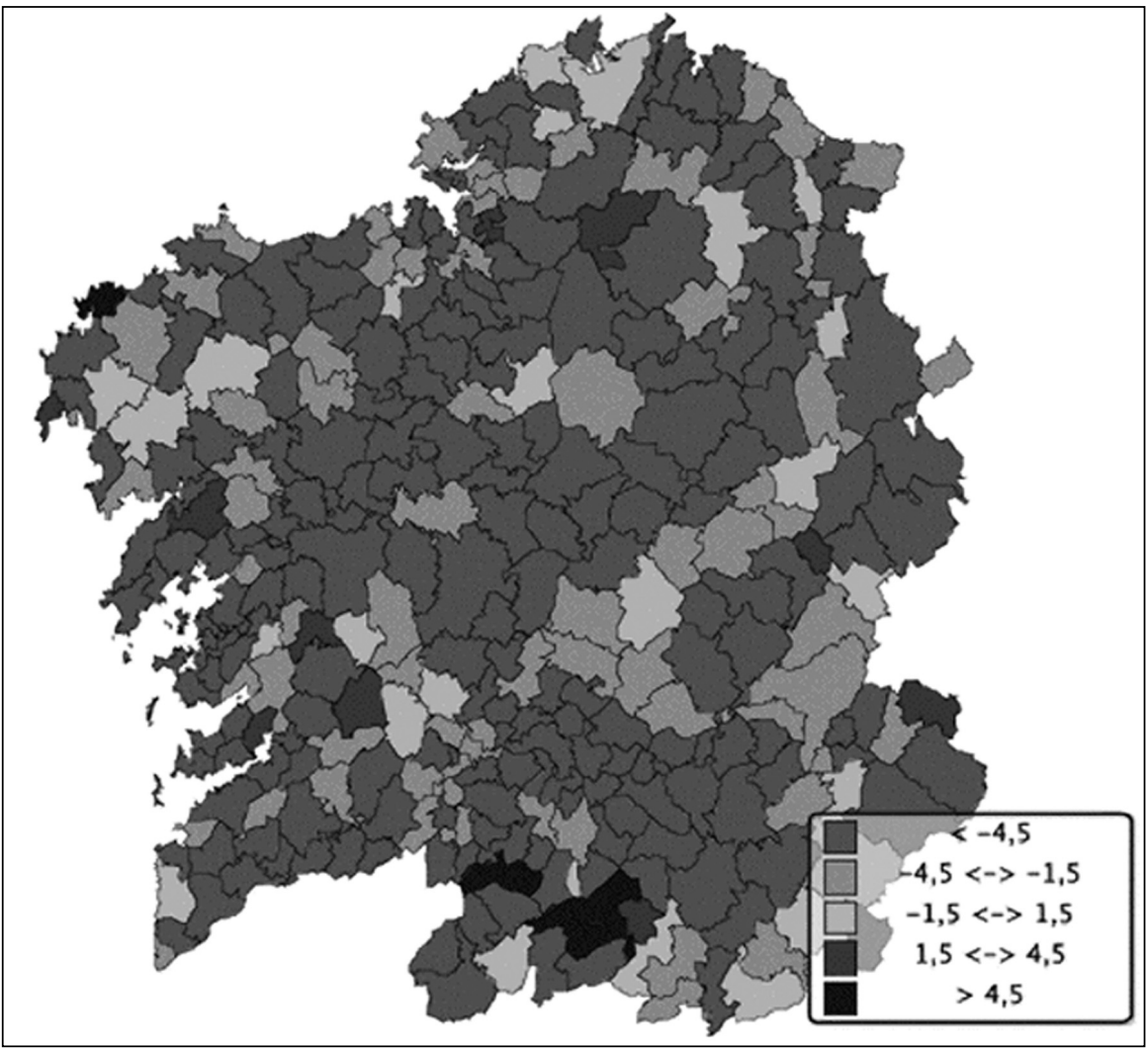

Fonte : Elaboração própria a partir de dados institucionais tirados de www.eleccionsgalegas2005.org/xunta.es.

30000 votos), o BNG é um sócio indispensável para o PSOE, superando o $20 \%$ dos votos nas zonas metropolitanas de maior crescimento demográfico. Mas o que mostra os resultados eleitorais é que os nacionalistas galegos são totalmente vulneráveis à dinâmica estatal, porque é agora, quando o PSOE voltou ao governo em Madrid, que os socialistas recuperam muitos votos na Galiza, o que lhes resta espaço eleitoral. Da mesma forma, os melhores momentos do BNG terão sido a começos da década de 90, quando o PSOE tinha caído no desprestígio por causa da corrupção e a divisão interna, tendo sido na Galiza um partido sem qualquer projecto. Na campanha eleitoral, o BNG saía também com o pejo dum ciclo negativo de dois anos de fortes brigas internas, que coincidiu com um importante processo de renovação, o qual apenas teve comparação com o realizado no PSOE em 2000, quando Zapatero ganhou o congresso socialista a José Bono, embora as circunstancias fossem diferentes. No processo de renovação do BNG há que salientar o efeito negativo, não tanto da ausência de Xosé Manuel Beiras na candidatura senão do impacto das suas críticas à estrutura do partido, aproveitadas com oportunismo pelo Partido Popular durante todos estes meses. 


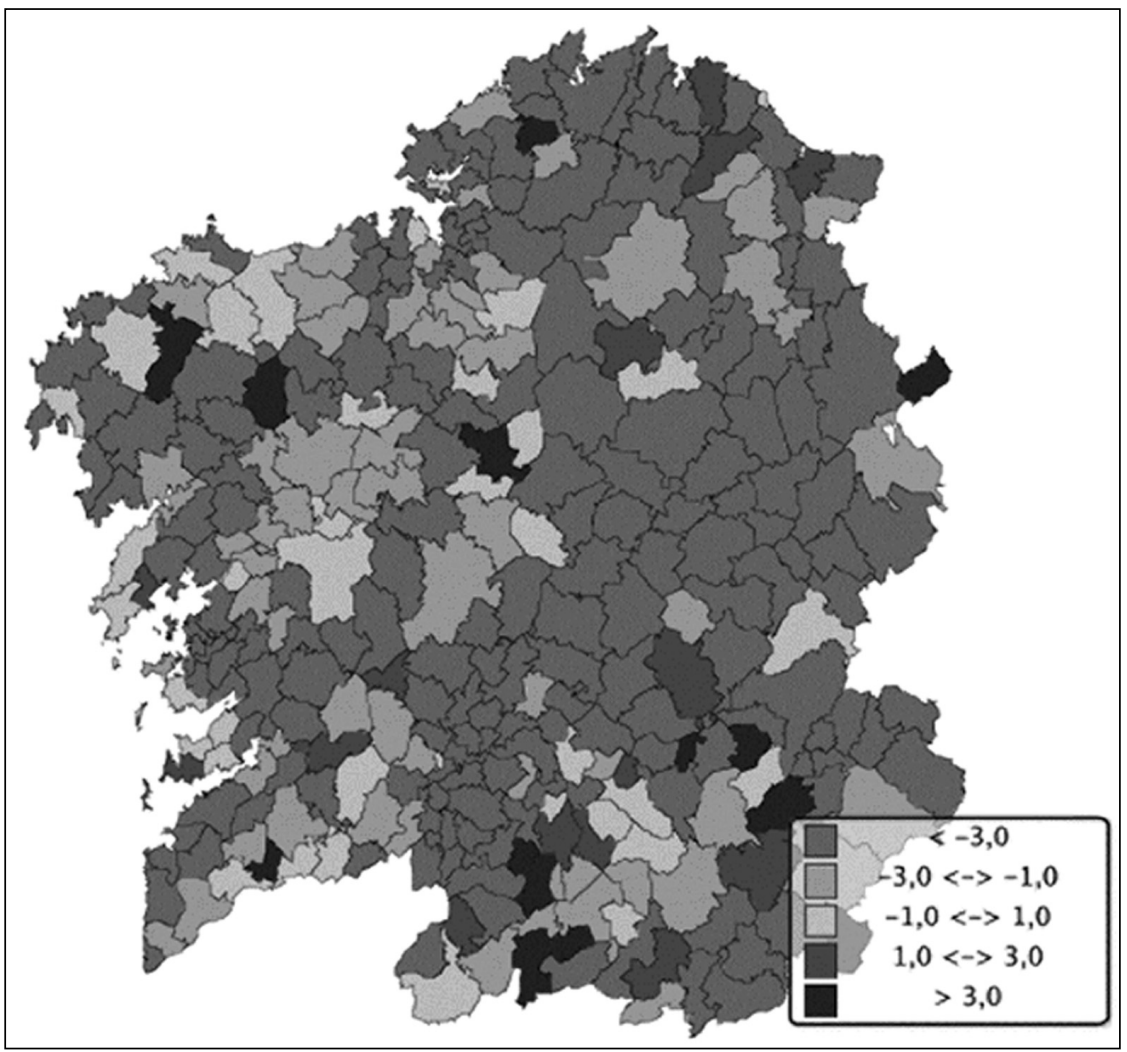

Fonte: Elaboração própria dados institucionais tirados de <www.eleccionsgalegas2005.org/xunta.es $>$.

Uma análise já clássica na geografia eleitoral galega identifica a enorme fonte de votos conservadores do interior rural com práticas de favoritismo alicerçadas nas relações pessoais. Ora bem, ante os últimos resultados eleitorais podem tirar-se duas conclusões: uma, ou bem o aparato clientelar conservador entrou em crise ou bem as novas gerações do rural mais próximo às cidades e o interior montanhoso (Ancares e Fonsagrada, importantes bolsas de votos socialista) já não entram tão facilmente no jogo de favores e simpatias locais. Outro factor a considerarmos será o impacto da peri-urbanização, que obriga a muitas famílias urbanas jovens a residir em municípios predominantemente rurais, mas próximos das cidades, aonde levariam uns hábitos políticos diferentes aos tradicionais.

Todavia, como explica Roberto Ridao ${ }^{6}$, a perda do poder do PP pode ser vista de forma diferente segundo a perspectiva escolhida. Assim, os 38 deputados de PSOE/BNG e os 37 deputados do PP é a prova da bipolarização existente no

${ }^{6}$ Tempos Novos, 98, Julho de $2005: 14$. 
País. Em todo o caso, o certo é que o comportamento eleitoral de Galiza não foi tão diferente ao de outras autonomias, pois também ali é difícil desbancar o primeiro partido governante na autonomia. A diferença da Galiza então consiste, contrariamente ao acontecido em 1989, na forte aposta do PSOE estatal num governo de coligação alternativo ao da Direita.

Ora bem, é certo que o resultado 38/37 falseia em certa maneira o panorama eleitoral galego, pois se temos em conta o que é anunciado como uma iminente reforma da lei electoral, os resultados do PP seriam sem dúvida muito piores. De resto, os populares poderão contar com alguns deputados menos após o seu Congresso do PP, caso se produzir uma cisão. Porém, a vários meses do Congresso, ainda há muito margem para a manobra. Desta sorte hoje em dia temos apenas um facto: o PP segue a ter um deputado menos que o governo e por isso representa ainda uma oposição com uma posição de força, pelo menos na teoria. Talvez isto seja uma prova de que o processo de mudança não é tão claro nem tão fácil como querem fazer ver o PSOE e o BNG.

Em todo o caso, temos que com estes resultados a Galiza deixa de ser um refúgio para a Direita e o PSOE-PSdeG aparece como autêntico ganhador das eleições, trás assumir a Presidência e a maior parte das conselharias. Foi fundamental a sua imagem de unidade (face a PP e BNG) e ofacto de dispor finalmente dum projecto para Galiza (não necessariamente galeguista), com propostas teóricas vindas de fora da estrutura formal do partido e o apoio do Governo central. A presença do Presidente espanhol na campanha eleitoral deu maior credibilidade às promessas eleitorais socialistas, mas viu-se também como um gesto decisivo do governo espanhol, nada desdenhável, a criação dum «embaixador para a emigração » em América, sem uma sede concreta, que atirou um voto emigrante mais atento à cor do governo espanhol que à do galego.

\section{Estratégias dos partidos após as eleições}

Como já vimos, as eleições de Junho deixam um panorama político de mudança no sistema político que implica fundamentalmente a perda do poder da Direita e a ascensão ao governo dos dois partidos da oposição. No entanto, os resultados não garantem uma legislatura estável nem um governo sólido, pois o PP, desde que não se produza uma cisão, continua a representar o grupo parlamentar mais numeroso, com 37 deputados de 75. Portanto, a situação do PP é resumida por alguns como uma «derrota doce», levando em conta a perda de carisma de Manuel Fraga, que associava na sua pessoa o declínio físico com a ruína do seu regime, devido as cada vez mais evidentes lutas de poder dentro do seu partido.

A derrota do PP poderia ter sido muito pior, talvez, se o líder do PP estatal e da oposição no Congresso espanhol, Mariano Rajoi Brei, não tivesse desembarcado em plena campanha galega. Assim, durante a última fase da campanha, Rajoi já não pedia o voto para Fraga Iribarne, que estava a fazer a pior campanha de sempre, senão que o pedia explicitamente para ele próprio, apesar de não aparecer em nenhuma lista do PP na Galiza. Seja como for, mais além do polémico e do significativo que isto foi, a sua intervenção ajudou ao PP a remontar nos inquéritos e maquilhou certamente a derrota de Manuel Fraga Iribarne, 
colocando esse adjectivo de «doce», uma vez que se evitou uma fuga de votos maior em favor do PSOE de Perez Touriño.

Para já, portanto, tudo são incógnitas e não se sabe o que pode acontecer no PP galego. Em qualquer caso, a estabilidade da legislatura dependerá do resultado da sucessão de Fraga Iribarne; nos próximos meses decidir-se-á a linha do partido e a sua contribuição para a vida parlamentar galega dos seguintes quatro anos. A escolha está entre um tipo de partido mais «galeguista », com mais independência a respeito de PP espanhol e portanto com mais capacidade para negociar no Parlamento as novas políticas, e um modelo de partido afim a Madrid, que representará para o novo governo de socialistas e nacionalistas galegos um obstáculo constante para as reformas que hão-de ser enfrentadas nos próximos anos. Ora, seja qual seja o resultado do processo de sucessão de Fraga Iribarne, as eleições fizeram manifesto que o PP retrocede em intenção de voto e está em condições de perder a sua condição de partido hegemónico na Galiza. Para evitálo, deve modernizar o seu discurso, tratando de captar um voto de centro cada vez mais volátil, como também mobilizar essa percentagem de voto abstencionista que se irá reduzindo progressivamente até alcançar percentagens parecidas com o sistema político espanhol.

A perda do poder do PP demostra a verdadeira natureza da crise no partido, incapaz de adaptar-se a uma nova dinâmica eleitoral e uma nova realidade socioeconómica. Até agora, o modelo de partido que representava o triúnviro formado pelos Presidentes das Deputações provinciais (Baltar, Cacharro Pardo e Rafael Louzán) mais a figura emblemática do antigo homem de confiança do presidente da Xunta, José Cuíña Crespo, controlava uma importante quantidade de recursos, muito úteis para forjar as sucessivas maiorias absolutas. Mas esse modelo entrou em crise há tempo. Cúñna caiu em desgraça a começos de 2003, quando foi cessado no seu cargo de conselheiro de Política Territorial. Ele foi a primeira e única demissão trás o Prestige. Mais tarde, Fraga Iribarne mostrava a sua decisão de preterir o sector galeguista na corrida da sucessão, ao nomear dois Vice-presidentes, Xosé Manuel Barreiro e Alberte Núñez Feijóo, mais afins a Madrid, sobretudo o último deles. As eleições pretendiam ser um lenitivo para o partido, mas em realidade acabaram por alterar os planos de Fraga, acelerando o processo de sucessão. Portanto, agora que o PP passa para a oposição, a direcção estatal quer aproveitar o ensejo para varrer da cena os rebeldes. Alberte Nuñez Feijoo é o candidato que tem o apoio de Rajoy mas é Barreiro o candidato que parece reunir um maior consenso. Durante a campanha eleitoral Xosé Cuiña mostrou - em presença de Rajoi - a disposição de lutar pelo liderado do partido na Galiza, seguro da relevância que ele e Baltar conservam no partido. Com efeito, o PP só conseguiu manter o número de votos no Interior (Ourense, feudo de Baltar, é a única província onde o PP superou o $50 \%$ dos votos) enquanto a maior perda de votos se deu em Pontevedra, onde o líder da candidatura era Nuñez Feijóo e onde Cuíña fora preterido até a quinta posição.

Todavia, pode pensar-se que a unidade do PP na «travessia do deserto » parece beneficiar a todos. Nesse sentido, Justo Beramendi, catedrático de História Contemporânea da universidade compostelã, acredita que o PP só tem esperanças de voltar ao poder em quatro anos no caso de se manter unido, e pode fazê-lo 
unicamente se encontra um novo líder que restabeleça o consenso, tal como fazia Fraga Iribarne. Ora bem, sem o «totem Fraga » a ameaça de guerra civil é muito alta e o mais provável, a meio prazo, é que o partido se rompa, pois o líder popular já demostrou nos últimos meses de governo que não controlava as disputas no seu partido, cada vez mais evidentes. Se a sombra da cisão semelha algo afastada, para já, o PP vai chegar dividido ao Congresso extraordinário do mês de Outubro.

Em resumo, Cuíña, apoiado por Baltar, vai apresentar batalha pelo controlo do partido e para impor uma «linha galeguista, autónoma de Madrid e próxima à realidade da rua ». Estará Mariano Rajoi em condições de fazer-lhes frente?

\section{O futuro do governo bipartidário}

Para evitar conflitos no seio do novo governo PSdG-BNG, será fundamental tanto a sensibilidade do PSOE ao galeguismo, como que o BNG evite as demandas maximalistas e o enfrontamento com o governo socialista em Madrid. Com certeza, será importante para o futuro do governo bipartidário o relacionamento com o Estado central e nos próximos meses, quando se apresentem os novos orçamentos estatais, o governo galego poderá comprovar a eventual existência de um « governo amigo » em Madrid, capaz de pagar, como fez no caso andaluz, a dívida estrutural do Estado com o território autónomo.

Além disso, estará sempre presente durante a legislatura o referente do governo tripartidário de 1987-1989 e também os exemplos basco e catalão. No primeiro caso, os socialistas bascos chegaram a estar num governo de coligação com os nacionalistas de direitas, mas aproximaram-se do PP, com quem coincidiam na política anti-terrorista. No segundo caso, cabe lembrar que o PSOE de Catalunha é abertamente catalanista e goza de mais independência a respeito da organização estatal, ao contrário do que acontece no caso do PSOE de Touriño, onde existe ainda um sector muito importante dentro do partido pouco ou nada galeguista, que se posiciona contra os acordos com o BNG.

Ora bem, acreditamos que se o PSOE quiser progredir eleitoralmente deve aplicar-se um verniz galeguista, tal como já fez o PP no passado, porque só com um projecto de governo pensado desde a Galiza e para a Galiza pode estar em condições de solucionar os problemas do País e o que é ainda mais importante, ser percebido como tal pela cidadania. Há-se de ver como funciona a coligação quando o conselheiro de Presidência é Méndez Romeu, homem de confiança da estrutura estatal do PSOE e em tempos muito próximo de Francisco Vázquez (Presidente da Câmara da Corunha e fervoroso anti-galeguista). Nesse sentido, acreditamos que os socialistas estão conscientes de que chegam ao governo pelo desejo de mudança expressado pela cidadania galega, e que boa parte desses 200000 novos votos são «prestados » por aqueles votantes desiludidos, quer com a saída de Beiras dos cargos de responsabilidade no BNG, quer pelos votantes do PP molestos com a quinta candidatura de Fraga à Presidência da Junta.

Seja como for, vai ser difícil a coabitação com o sócio, porque Quintana (líder do BNG) quer um tratamento de nação para Galiza e tem uma visão do processo de normalização do galego que choca radicalmente náo somente com a do PP mas também com a dos seus próprios sócios de governo. O desafio pois é 
manter uma coligação de dois partidos com ideologias e aspirações diferentes. Por outra parte, é difícil conhecer, em opinião de Pedro Árias Veiga, os instrumentos que o BNG utilizará para impedir um transvase de votos ao $\mathrm{PSOE}^{7}$. È claro que este é um risco que também correm os socialistas, na medida em que ambos partidos partilham algumas das suas bases eleitorais. Em todo o caso, apesar de que o Bloque já teve horas melhores, retém ainda uma importante base eleitoral que lhe garante poder no Governo e capacidade para continuar o necessário processo de renovação dentro do partido. Certamente, o BNG tem uma posição pior para competir pelo centro que outorga a hegemonia eleitoral, em parte porque tem ainda um grande peso ideológico, pelo menos se o compararmos com o PSOE. É isso o que tem de revisar. Anxo Quintana começa bem, escolhendo um discurso pragmático e directo, nada alambicado, embora seja certo que na repartição das conselharias segue a dominar a estrutura dos comunistas da UPG.

O tecto eleitoral contra o que bateu o BNG sob o liderado de Xosé Manuel Beiras só pode ser superado se os nacionalistas demonstram a capacidade de atirar o voto de muitos votantes do PP e do PSOE. Por isso, o BNG deveria aproximar-se dos problemas reais das pessoas, dando menos importância às questões ideológicas, pelo menos face ao exterior. Por outras palavras, o BNG tem que modernizar o seu discurso (sobretudo a UPG pela sua relevância e que segue ainda ancorada nos anos 60 ou 70) essencialmente porque a maior parte da população galega não entende a sua identidade galega em contradição com a espanhola, mas tudo o contrário.

Ora, independentemente da evolução seguida pelos dois sócios de governo, acreditamos que a derrota do PP e a chegada ao governo da Esquerda supõe um novo passo, talvez o decisivo, para a integração do sistema político galego no sistema político espanhol. Desta maneira, a Galiza cobra importância no debate geral sobre as reformas na estrutura territorial do Estado e sai do isolamento que supus a "pax fraguiana". Assim, a aposta firme de Zapatero na coligação de socialistas e nacionalistas tem implícito um desejo de mudar o esquema de apoios ao governo socialista a nível estatal, porquanto Zapatero anda à procura de novos aliados, não apenas para isolar ainda mais o PP de Rajoi, mas também para evitar os problemas derivados da aliança táctica com partidos como ERC (independentistas catalães). Ao mesmo tempo, chegar a um entendimento com o Bloco equivale para Zapatero a confrontar um modelo de reforma territorial negativo, representado pelo governo de coligação catalão, com um modelo positivo, que representa a Galiza, onde Touriño está muito longe de parecer-se com Maragall, o Presidente catalão, muito mais federalista, e onde Quintana apesar do que se diga, não é um Carod-Rovira (o líder de ERG).

O contexto político espanhol permitiu enfim a maior cumplicidade da estrutura estatal do PSOE nas eleições galegas. Certamente, nas eleições de 1989, mas sobretudo nas de 1993, Felipe González, presidente espanhol naquela altura, preferia ter na Galiza um bastião da Direita que funcionasse assim como um contrapeso aos nacionalismos periféricos basco e catalão. Hoje em dia, Zapatero concentra o seu interesse na Galiza por motivos semelhantes, mas a diferença está em que

7 La voz de Galicia, 14 de Agosto de 2005 : 13. 
hoje é possível, e portanto necessário, deslocar o PP do governo, mesmo apesar dos riscos que supõe uma coligação com um partido que compete por um espaço eleitoral em parte coincidente.

Um analista político como Xoán López Facal escrevia que o PP se encontra ainda em estado de shock e por isso consumirá os próximos meses no processo de readaptação ${ }^{8}$. Seja como for, ainda está por ver se o PP será capaz de superar o legado do "cesarismo fraguista », educando a «direita hispano-regionalista nos valores de pluralismo e a equidade do exercício do poder, estabelecendo uma relação próxima com a cidadania ». Para Facal, em suma, o PP tem que passar, com palavras do sociólogo Max Weber, de viver da política a viver para a política, enquanto o PSOE e sobretudo o BNG, hão-de passar da militância e o idealismo ao governo e o pragmatismo, cedendo o poder aos cargos eleitos que serão os que façam a política prática. Em resumo, Facal entende que os agentes políticos galegos hão-de devolver a primazia à política propriamente dita, deixando atrás a «governação conservadora », que supus um governo de tecnocratas.

\section{O programa de governo conjunto PSOE-BNG}

A derrota do PP abre a possibilidade para a posta em prática de políticas alternativas nos terrenos económico e cultural demandadas pela sociedade galega, como podem ser a regeneração democrática e a procura da eficiência e transparência na despesa pública. Tais políticas vão exigir sem dúvida ao governo importantes reformas, nomeadamente no que diz respeito ao Estatuto de Autonomia, mas também no referido à lei eleitoral galega, a fim de revisar o sistema de voto dos emigrantes, introduzir o critério da paridade de género na representação e dar cabo da sobrerrepresentação das províncias do interior, elemento introduzido por Manuel Fraga em 1990 e chave para explicar as maiorias absolutas da Direita.

Aliás, o novo executivo fala na necessidade de realizar uma auditoria geral da Administração galega, como também de redigir uma nova lei de subvenções. É uma necessidade agrupar todas as empresas semipúblicas criadas durante o mandado de Fraga Iribarne, na medida em que se converteram no método mais comum para estender o clientelismo à actividade administrativa, favorecendo assim a fuga de capitais públicos ao exame do Conselho de Contas. O novo governo enfrenta também o problema da manipulação informativa de que adoecem a rádio e a televisão públicas (e não só, porque os média privados, sobretudo jornais, dependem em boa medida das subvenções da Junta para sobreviverem). O país precisa ainda de modernizar sectores económicos estratégicos, para estar em condições de manter uma posição no mercado internacional que já é boa, mas que pode ser melhor. E, sobretudo, necessita um pacto pelo emprego dos agentes sociais que não se deu no governo Fraga para combater a instabilidade e a fraude na contratação.

A controvérsia estará por um lado no debate sobre o carácter nacional da Galiza, no que não acredita boa parte dos socialistas galegos, e por outro a

${ }^{8}$ X. López Facal, «Apuntamentos para unha nova axenda política », Tempos Novos, 98, Julho de 2005 . 
satisfação do Governo central do que os nacionalistas chamam « dívida histórica » do governo central com a Galiza extensível às matérias de emprego, ensino, sanidade e infra-estruturas. Além do debate semântico (o PSOE fala de «défice estrutural»), há uma realidade de atraso das políticas estruturais do Estado no território galego, que também foi reclamado (com êxito) ao Presidente Zapatero desde a Andaluzia.

É preciso lembrar que a Galiza continua a ser uma das regiões menos desenvolvidas de Espanha e, portanto, a acção do governo, tanto em etapas anteriores quanto na nova etapa recém-inaugurada, visa paliar os ainda importantes défices estruturais que padece a região. Estes défices cobrem todo um conjunto de áreas que vão desde o emprego às prestações sociais, passando pelas infra-estruturas, a qualidade dos meios de comunicação autonômicos ou as políticas de inovação industrial e empresarial. Em princípio, parece que os partidos que formam o novo governo (e sobretudo o BNG) pretendem dar resposta a estas deficiências estruturais através da demanda de um maior e melhor autogoverno com repercussão no processo de reforma do Estatuto de autonomia da Galiza. No entanto, todo o PP e não poucos membros e simpatizantes do PSdeG-PSOE são contrários a uma forte aprofundamento do autogoverno galego por considera-lo « um tema menor que não preocupa a ninguém ». Neste sentido, estes últimos actores políticos reclamam como alternativa o estrito cumprimento dos compromissos do «Plano Galiza »"

O intuito comum a socialistas e nacionalistas de formar um governo de coligação, que fosse a expressão do desejo de alternância democrática na Galiza propicia que exista uma boa sintonia inicial entre o novo presidente, Emilio Pérez Touriño e o novo vice-presidente, Anxo Quintana. Assim, num piscar de olhos aos sócios nacionalistas, Touriño afirma que a Galiza deve ser tão ambiciosa em termos de autogoverno quanto qualquer outra comunidade de Espanha (clara referência a Catalunha e ao País Basco), pois a Galiza deve «incorporar-se à Espanha da primeira velocidade em todos os âmbitos, inclusivamente o político », deve "construir-se país » e «acabar com os localismos » que dividem a sociedade galega em Norte e Sul, Leste e Oeste. Quintana incide, pela sua banda, nas constatações de que a «Galiza leva já décadas fora das prioridades investidoras do Estado » e de que « é necessário para o bem-estar dos cidadãos a contribuição da Galiza à construção de um «Estado composto por nações livres que se falam de igual a igual na procura de soluções comuns $»^{10}$. Existem pois condições para formar um governo estável para os próximos quatro anos.

Com efeito, o BNG alcançou o seu desejo de lograr uma vice-presidência única com muitas competências, à maneira duma macroconselharia, com competências em temas sociais e que dará ao BNG maior presença nas instituições estatais, ao ter sob a sua dependência uma Secretaria Geral de Política Institucional, que será

9 O «Plano Galiza » é um plano de investimentos públicos do Estado espanhol para a construção de infra-estruturas fulcral para o desenvolvimento económico da Galiza, lançado como medida de urgência para minorar os efeitos da maré negra provocada pelo naufrágio da nave petroleira «Prestige» em Novembro de 2002. Naquela altura, o PP de Fraga governava na Galiza e o mesmo partido, com Aznar à frente, governava Espanha.

${ }^{10}$ Discursos do «Dia da Pátria Galega », de 25 de julho de 2005 do PSOE e BNG, transcritos na A Nosa Terra, 1 186, 27 de Julho-3 de Agosto de 2005. 
a encarregada de negociar com o Governo central os três temas básicos na próxima legislatura, isto é, as novas competências, as transferencias orçamentárias e o autogoverno. Além disso, o BNG encarrega-se duma parcela governamental que sempre considerou básica, o desenvolvimento integral do País. Não vai dirigir apenas a Conselharia de Médio Rural, mas também a política industrial, cos seus diferentes organismos: o I + D + i, o Turismo, Solo e polígonos industriais, Agências de promoção agrária e Agências nas comarcas, etc. No entanto, a base e núcleo fundamental da acção de governo corresponde-lhe ao PSdeG-PSOE, com a Presidência e oito conselharias (economia e serviços básicos), encarregando-se das principais competências em serviços públicos, planificação económica, financeira e de infra-estruturas e políticas sectoriais de importância como Pescas, Médio Ambiente e Trabalho. A tendência geral de resto é a simplificação do mapa de conselharias, desaparecendo três delas e repartindo-se as suas competências entre as outras.

Touriño e Quintana coincidem em dar-lhe a primeira prioridade às políticas de emprego, igualdade e serviços públicos, seguidas pelas iniciativas que visam restabelecer o equilíbrio territorial, defender o meio rural e os montes. Outro ponto de singular importância no programa apresentado pelas duas forças é o dedicado à "regeneração democrática » que visa acabar com as evidentes ocultações e manipulações informativas operados a favor do anterior governo pelos médios públicos de comunicação da Galiza (rádio e televisão) e de vários jornais regionais de clara orientação conservadora. Em resumo, a futura acção de governo do bipartidário alicerçar-se-á em três eixos fundamentais : o reforço do autogoverno e da coesão social, o desenvolvimento territorial equilibrado e o impulso dos sectores produtivos estratégicos da Galiza.

Todavia, o grau de concreção das bases programáticas do novo governo é forçosamente limitado, centrando-se nos principais objectivos para a etapa 20052009: emprego de qualidade, investimento em capital humano, sistema de bemestar avançado, compromisso com a igualdade real entre os sexos e desenvolvimento sustentável do território e normalização lingüística. Todos estes objectivos ligamse ao aprofundamento no autogoverno através de um novo Estatuto e à regeneração democrática mediante a eliminação do clientelismo e a introdução de sistemas para a transparência no funcionamento dos organismos públicos e dos meios de comunicação. Este último fim exige várias medidas urgentes, como por exemplo, a criação duma lei sobre a transparência na despesa pública, uma nova lei que regule as subvenções, uma reforma da lei eleitoral, outra lei que determine os limites para a publicidade institucional, para além da eleição consensual do Director da comunicação social de propriedade pública, fomentando a presença do galego e da cultura galega em geral na comunicação social privada.

Relativamente às Autarquias, o novo governo tenciona incrementar a autonomia local, garantindo a sua suficiência financeira directamente com partidas procedentes dos orçamentos da Autonomia. No que diz respeito à ordenação territorial, impulsar-se-ão as comarcas, as regiões e as áreas metropolitanas (prima a visão nacionalista do território como País e não como suma de cidades, como queriam os socialistas), coordenando o trabalho das deputações (ainda feudo daqueles que lhe deram as maiorias a Fraga Iribarne) através dum Plano Único de Obras e Serviços. 
No relacionamento com o Estado, o novo governo quer negociar a correcção do «défice estrutural » (dívida histórica para os nacionalistas) em temas de emprego, ensino, saúde e infra-estruturas, assim como no acordo das transferências pendentes, a participação real da Galiza nas instituições europeias e na regulação dos temas económicos que lhe atingem especialmente, inclusivamente a reforma das instituições para permitir a representação galega em Bruxelas. $\mathrm{O}$ acordo de governo fala na projecção europeia da Galiza, a partir da presença em negociações e através do impulso das relações galaico-lusas, no contexto do "Convénio de Valença ", como também da difusão exterior da língua e a cultura galegas, dedicando um $0,4 \%$ dos orçamentos da Comunidade à cooperação exterior.

No campo da inovação industrial e empresarial, fala-se no desenvolvimento das pequenas e medianas empresas, fomentando as economias de proximidade e o fortalecimento do tecido industrial local, melhorando as interconexões, a logística e o apoio às iniciativas de $\mathrm{I}+\mathrm{D}+\mathrm{i}$. Isto significará, segundo o acordo, a duplicação do investimento para lograr que em quatro anos esteja nos 1,5\% do «PIB galego ", com maior participação privada. Também se fala em extensão das telecomunicações, a criação de clusters, um Plano estratégico da Sociedade da Informação, a incorporação dos investigadores às empresas e centros de investigação, unificando os órgãos de financiamento e apoio aos empreendedores, incrementando os fundos de «capital-semente » e por último, fala-se na criação duma lei do comércio galego, do impulso dos parques tecnológicos e a promoção do sector audiovisual galego, que visará a difusão da imagem e a cultura galegas no exterior.

Ora, um dos desafios mais importantes que o novo governo tem por diante é a melhora das prestações económicas e de competitividade do tecido produtivo galego, caracterizado pela predominância de empresas pequenas e familiares que não fazem excessivos esforços por participar nos empreendimentos e actividades das grandes empresas ou por alargar os seus mercados a espaços mais abrangentes. Isto supõe um problema de especial gravidade, se levarmos em conta a próxima perda dos fundos europeus de coesão e a urgente necessidade de criar empregos estáveis e de qualidade para reter à população jovem. Aliás, a baixa qualidade do emprego na Galiza é um forte factor de estrangulamento, posto que a maior parte dos trabalhos que se ofertam não requiram uma alta qualificação, ao representar um pejo para a futura capacidade de concorrência das empresas. Neste âmbito, o PSdeG comprometeu-se a converter em indefinidos um terço dos contratos no sector privado e a metade dos contratos no sector público, enquanto o BNG propõe incrementar até o $1,1 \%$ do PIB o orçamento para políticas activas de emprego. A nova Conselharia de Trabalho, nas mãos do PSdeG, tem um importante labor pela frente. O BNG terá responsabilidades nos principais sectores económicos: na política agrícola deverá empreender acções conduzentes à eliminação da excessiva dependência de subvenções e ajudas. Na política industrial deverá enfrentar às crescentes necessidades de solo industrial, tanto para a implantação de novas fábricas quanto para o traslado de algumas já existentes (como a fábrica de pasta de papel ENCE, de Pontevedra).

Em relação ao ensino, o acordo coloca como prioridade do governo alcançar a plena competência em galego, espanhol e uma língua estrangeira. Em relação com o ensino do galego, o governo tenciona cumprir o Plano de Normalização aprovado no final do governo de Fraga Iribarne, aumentando contudo a aposta 
educativa e formulando objectivos mais ambiciosos (lei de universidades galegas, aumento de bolsas, curriculum de investigador, criação da universidade virtual galega, etc.). Assim, o propósito do governo em relação ao galego é mais ambicioso ou simplesmente mais activo, porque busca recuperar falantes, estender o uso normal do galego e aumentar a comunicação com os outros países de língua oficial portuguesa.

Por último, no que diz respeito ao território e os temas ambientais, o acordo recolhe a famosa percentagem do $8 \%$ de investimentos mínimos exigidos ao Estado de despesa em infra-estruturas, necessária para a melhora da produtividade, do crescimento e a convergência real com Espanha e Europa. Fala-se também num «Pacto pelo território », que visa a conjugação da sustentabilidade ambiental com a económica e social, ordenando os investimentos e estabilizando o marco legal, ao mesmo tempo que afiançando o respeito pelo território e o médio ambiente rural e urbano, no caminho até a convergência com o Convénio de Quioto. O texto do acordo recolhe neste sentido ideias interessantes como a regeneração, a preservação e o saneamento integral das rias, que implica com certeza a negociação para o traslado da fábrica de celulose situada hoje no fundo da ria de Pontevedra. Mas também implica revisar a política de barragens que está reduzindo escandalosamente o caudal e a vida dos rios galegos. Outro dos propósitos do novo governo é conservar os núcleos rurais como habitat populacional, sem deixar de inserir as cidades galegas na euroregião. $\mathrm{O}$ uso racional do solo, por outra parte, exige a revisão da legislação relativa deixada pelo PP. O novo governo prometeu também pôr no mercado 25000 moradias de protecção oficial, 7000 delas em regime de aluguer.

Desde o ponto de vista territorial, é particularmente interessante a proposta de novo ordenamento realizada. A Galiza passaria a ter instituições de gestão territorial ao nível das regiões metropolitanas, regiões urbanas e áreas funcionais, compostas da união de várias comarcas vizinhas com afinidades económicas e sociais e com um centro urbano reitor do conjunto do espaço funcional. Este novo ordenamento julga-se necessário para o desenvolvimento de infra-estruturas, serviços públicos e para a protecção do médio ambiente. Ao mesmo tempo, pretende-se dinamizar a escala macro-regional representada pela euro-região Galiza-Norte de Portugal e pelo eixo urbano atlântico, no que se concentram as principais estruturas de troca de conhecimento e inovação, para o desenvolvimento em comum, por exemplo, da indústria cultural e audiovisual ${ }^{11}$.

Neste último campo parece aberta uma via continuadora do trabalho iniciado na etapa de governo de Fraga Iribarne, que acusou ao novo governo de carecer dum programa próprio, pois se em certos temas vai continuar o que se considera um bom labor do anterior governo, noutros casos apenas se desqualificam as decisões tomadas, carecendo de propostas válidas e detalhadas sobre as melhores alternativas. Estas afirmações de Fraga Iribarne, não sendo completamente certas,

11 Neste âmbito, tiveram ampla repercussão iniciativas como a produção conjunta de filmes de animação por parte de empresas galegas e portuguesas (por exemplo «A floresta animada ", «Sonho de uma noite de São João »), ou a candidatura do «Património Imaterial GalegoPortuguês » para a consideração da Unesco como «Património da Humanidade ». 
têm grande parte de verdade, pois parece que o novo governo encaminha-se pelo trilho das reformas, estando mais preocupada pelo estilo do que pelo fundo das suas propostas políticas, que não deixam de ser propostas gerais em grande medida partilhadas pela totalidade da sociedade (também por uma parte apreciável da direita política e social). Seja como for, será preciso aguardar um tempo para observar e julgar os primeiros passos e decisões do novo governo.

O êxito do PP na Galiza foi o êxito de Fraga, mas se este teve tanto êxito na Galiza, explica M. Veiga no semanário A nosa terra, foi porque encarnou na sua figura o binómio identitario galego-espanhol em que se situam a maior parte dos galegos e galegas. Por outro lado, o PP levou sempre em conta a noção de progresso própria dum país de pequenos proprietários, onde sempre se viu o gestor eficiente como aquele que faz muitas obras; isso conectava, aliás, com a experiência dos emigrantes na América. O PP apostou nestes anos por gastar a maior parte dos orçamentos e dos fundos europeus na construção de infra-estruturas, que muitas pessoas seguem considerando no Interior como um favor pessoal obtido graças à intermediação do cacique perante o poder, encarnado durante tantos anos em Fraga.

A revitalização do Parlamento augurada por uns resultados eleitorais tão ajustados, pode abrir uma via para a recuperação da democracia na Galiza, através dum governo de coligação que expressa o desejo de alternância e de ruptura com as maiorias absolutas de Manuel Fraga Iribarne, que deixaram em palavras de Anxo Guerreiro, reaf ex-parlamentário de Esquerda Unida, « uma gigantesca rede clientelar sustentada com fundos públicos e um domínio das instituições públicas, semi-públicas e privadas que colocaram a Fraga e ao seu governo fora de toda crítica pública e mesmo privada $»^{12}$. Portanto, se até há pouco as prioridades de Fraga eram as do governo e as do País, gostaríamos de pensar que um governo de coligação poderá representar para Galiza uma etapa de recuperação saudável da democracia, desde que se devolva o protagonismo ao Parlamento, lugar privilegiado para a expressão do pluralismo da sociedade galega.

30 de Agosto de 2005

Carlos DIAS DIEGUES

Universidade de Santiago de Compostela, Departamento de Ciência Política

José Luís PALMEIRO PINHEIRO

Universidade de Santiago de Compostela, Departamento de Geografia

12 A. Guerreiro, «A urxencia da rexeneración democrática », Tempos Novos, 98, Julho de 2005 : 23-24. 